\title{
IESTORATION OF FRESHWATER IN THE
}

\section{AÑO TIBURONES AREA, PUERTO RICO}

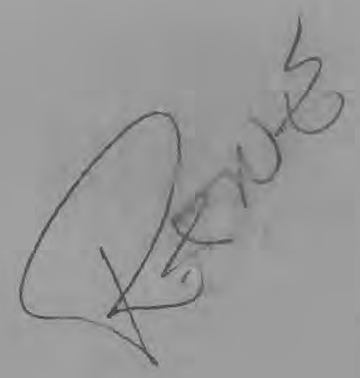

.S. GEOLOGICAL SURVEY

IATER-RESOURCES INVESTIGATIONS REPORT 83-4071

EXPLANATION $\sum_{0}^{1} z=0$

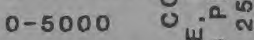

E000-10,000 000ّ

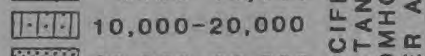

20,000-30,000 450

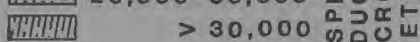

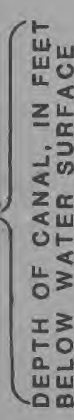

repared in cooperation with the UERTO RICO DEPARTMENT OF AGRICULTURE 


\section{RESTORATION OF FRESHWATER IN THE \\ CANO TIBURONES AREA, PUERTO RICO \\ By Allen L. Zack and Angel Class-Cacho}

\section{U.S. Geological Survey}

Water Resources Investigations Report 83-4071

Prepared in cooperation with the

Puerto Rico Department of Agriculture

San Juan, Puerto Rico

1984 


\title{
UNITED STATES DEPARTMENT OF THE INTERIOR
}

\author{
WILLIAM P. CLARK, Secretary
}

GEOLOGICAL SURVEY

Dallas L. Peck, Director

For additional information write to:

Chief, Carlbbean District, WRD

U.S. Geological Survey GPO Box 4424

San Juan, Puerto Rico 00936

(Telephone: (809) 763-4414)
Coples of this report can be purchased from:

Open-file Services section Western Distribution Branch U.S. Geological Survey Box 25425. Federal Center Denver,Colorado 80225 (Telephone: (303) 234-5888) 


\section{CONTENTS}

\section{Page}

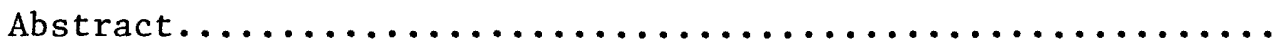

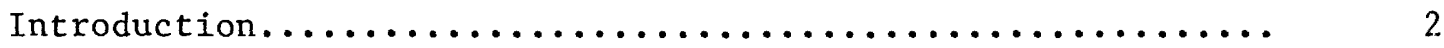

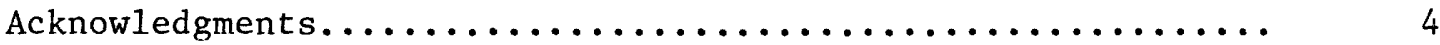

Description of the area............................ 4

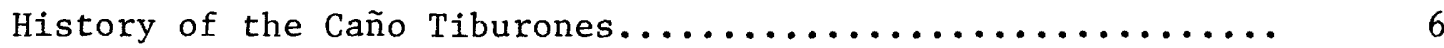

Surface hydrology of Caño Tiburones before water management.. $\quad 8$

Geohydrology $\ldots \ldots \ldots \ldots \ldots \ldots \ldots \ldots \ldots \ldots \ldots \ldots \ldots \ldots \ldots \ldots \ldots \ldots$

Segregation of saltwater and freshwater.............. 21

Containment of seawater entering Caño Tiburones........... 23

Testing equilibrium water level by stopping pumping at

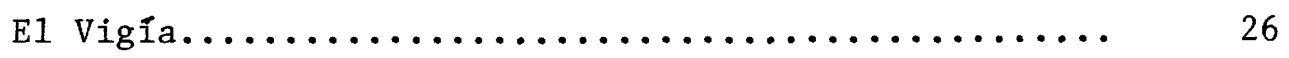

Measurement of freshening efforts in the Caño............ 28

Conclusions................................ 31

Selected references............................ 33

\section{ILLUSTRATIONS}

Page

Figure 1. Map showing Caño Tiburones and vicinity........

2. Map showing principal hydraulic structures, springs, and hydrologic-data collection sites in Caño Tiburones.............. (in Pocket)

3. Sketch showing the configuration of dilute seawater in Canal Norte and Canal Central of Caño Tiburones, July 20, 1979........ (in Pocket)

4. Sketch showing land surface altitude of Poza Dorada a seawater spring, or seep draining to the Canal Norte of Caño Tiburones........... 


\section{ILLUSTRATIONS (Continued)}

5. Graph showing the relation of sodium to chloride in water from canals and springs in Caño Tiburones....................

6. Graph showing relation of chloride and the ratio of calcium to magnesium in water samples withdrawn from wells, springs, canals, and the ocean in Caño Tiburones

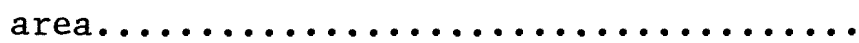

7. Sketch showing the configuration of dilute seawater in Canal Norte and Canal Central of Caño Tiburones, June $20,1980 . \ldots \ldots \ldots$ (in Pocket)

8. Sketch showing the configuration of dilute seawater in Canal Norte and Canal Central of Caño Tiburones, May 19,1982.............. (in Pocket)

9. Graph showing the water-level response to a pump stoppage at E1 Vigía pumphouse April 5-9, 1982

10. Graphs of the specific conductance of water at three sites in Caño Tiburones showing improvement in freshening due to reorganization of flow and containment of seawater springs.........

\section{TABLES}

Table 1.--Representative values of specific conductance, chloride, and water levels at various depths in we11s, Caño Tiburones.................

2. Representative values of specific conductance, chloride, and water levels at various depths within the blanket sands, Caño Tiburones...... 


\section{CONVERSION TABLE}

The following factors may be used to convert the inch-pound units published herein to the International System of Units (SI). This report contains both the inch-pound and SI unit equivalents in the station manuscript descriptions.

Multiply inch-pound units

\section{inches (in) \\ feet $(f t)$ \\ miles (mi)}

\section{Length}

$2.54 \times 10^{1}$
$2.54 \times 10^{-2}$
$3.048 \times 10^{-1}$
$1.609 \times 10^{0}$

Area

acres

square miles $\left(\mathrm{mi}^{2}\right)$

cubic feet per second $\left(\mathrm{ft}^{3} / \mathrm{s}\right)$

gallons per minute (gal/min)

$6.309 \times 10^{-5}$

million gallons per day (Mgal/d) $4.381 \times 10^{1}$

$$
4.38 \times 10^{-2}
$$

Specific Conductance
$1.000 *$
To obtain SI units

\author{
millimeters (mm) \\ meters (m) \\ meters (m) \\ kilometers $(\mathrm{km})$
}

liters per second (L/S) cubic decimeţers per second $\left(\mathrm{dm}^{3} / \mathrm{s}\right)$

cubic meters per second $\left(\mathrm{m}^{3} / \mathrm{s}\right)$

liters per second (L/s)

cubic decimeţers per second $\left(\mathrm{dm}^{3} / \mathrm{s}\right)$

cubic meters per second $\left(\mathrm{m}^{3} / \mathrm{s}\right)$

cubic decimethers per second $\left(\mathrm{dm}^{3} / \mathrm{s}\right)$

cubic meter per second $\left(\mathrm{m}^{3} / \mathrm{s}\right)$

micromhos per centimeter

(umho/cm)

microsiemens per centimeter $(\mathrm{uS} / \mathrm{cm})$ 


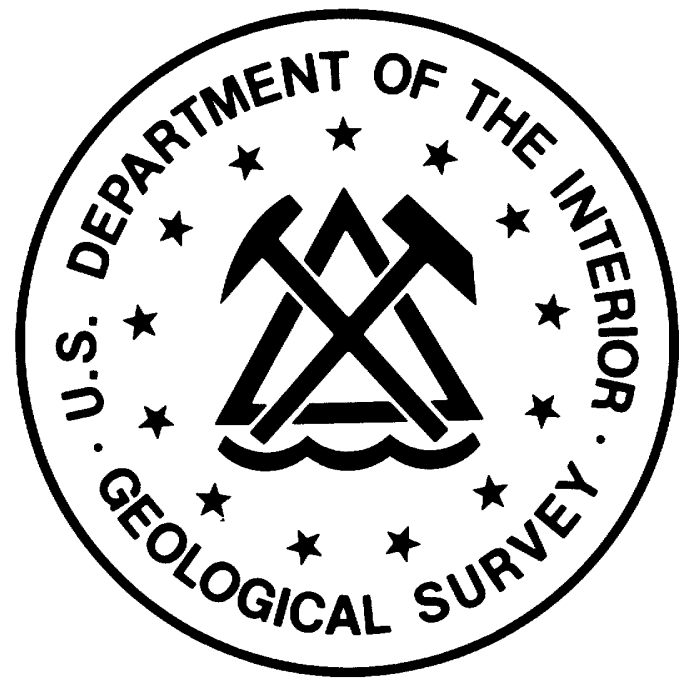




\title{
RESTORATION OF FRESHWATER IN THE CAÑO \\ TIBURONES AREA, PUERTO RICO \\ By Allen L. Zack and Angel Class-Cacho
}

\begin{abstract}
Caño Tiburones on the north coast of Puerto Rico originally was a shallow, coastal lagoon, 9 square miles in area. It accumulated freshwater from adjacent rivers and springs and drained to the ocean through unobserved subterranean conduits. Forced drainage by pumping of Caño Tiburones for agriculture was begun in 1949, and resulted in lowering the water level to below sea level. The reversed hydraulic gradient permitted seawater to enter the Caño through the conduits forming seawater "springs". Seawater flooding caused widespread sodium chloride contamination in the canals and laterals and in the soils. Agricultural expectations of the area were not realized.

The present investigation into the freshening potential of

Caño Tiburones (1979-1982) determined that ground-water discharge does not contribute to salty conditions.

On-site experiments were performed to segregate freshwater from seawater using differences in hydraulic head. Dams were constructed on canals and laterals, forcing accumulated saltwater to the ocean. Ring levees were placed around the discharging seawater conduits until sea level was reached and flow to the system stopped.

These efforts have succeeded in reducing the amount of seawater in Caño Tiburones to one-third of its original concentration. Most of the water presently in Caño Tiburones is suitable for irrigation.
\end{abstract}




\section{INTRODUCTION}

The Caño Tiburones is a swampy depression on the north coast of Puerto Rico, extending between Río Grande de Arecibo and Río Grande de Manatí (fig. 1). The area contains approximately 6,000 acres (9 square miles) and is the site of a partially successful land-reclamation project. Drainage of the land began in 1907 by the Puerto Rico Department of Agriculture. The hydraulic gradient between the water table in the Caño area and the ocean was reversed as a result of the drainage, and seawater began to inundate the Caño. The accumulations of sodium chloride in the canals and laterals of Caño Tiburones, as well as in the soil, rendered the area virtually unusable for agriculture.

The Caño Tiburones is owned by the Commonwealth of Puerto Rico and administered by the Land Auth- ority within the Department of Agriculture. The Land Authority leases tracts of land to local farmers principally for pastures. The high population density of Puerto Rico and limited quantities of flat agricultural land prompted the investigation of alternatives to recover the valuable Caño area.

The U.S. Geological Survey in cooperation with the Department of Agriculture, began a project in 1979 designed to study the water resources of the Caño Tiburones area and to answer the following questions:

1) Can the Caño Tiburones be made fresh?

2) How long will the freshening process take?

3) Can the water in the area be maintained fresh? 


\section{INTRODUCTION (Continued)}

The approach used to answer these questions was as follows:

1) Determine the source and route of saltwater into the Caño flow system.

2) Determine, through experimentation, the best methods of utilizing freshwater to purge accumulated saltwater while at the same time prevent seawater from further contaminating the water and soil in the Caño.

3) Monitor water quality in the system to assess the effects of the experiments.

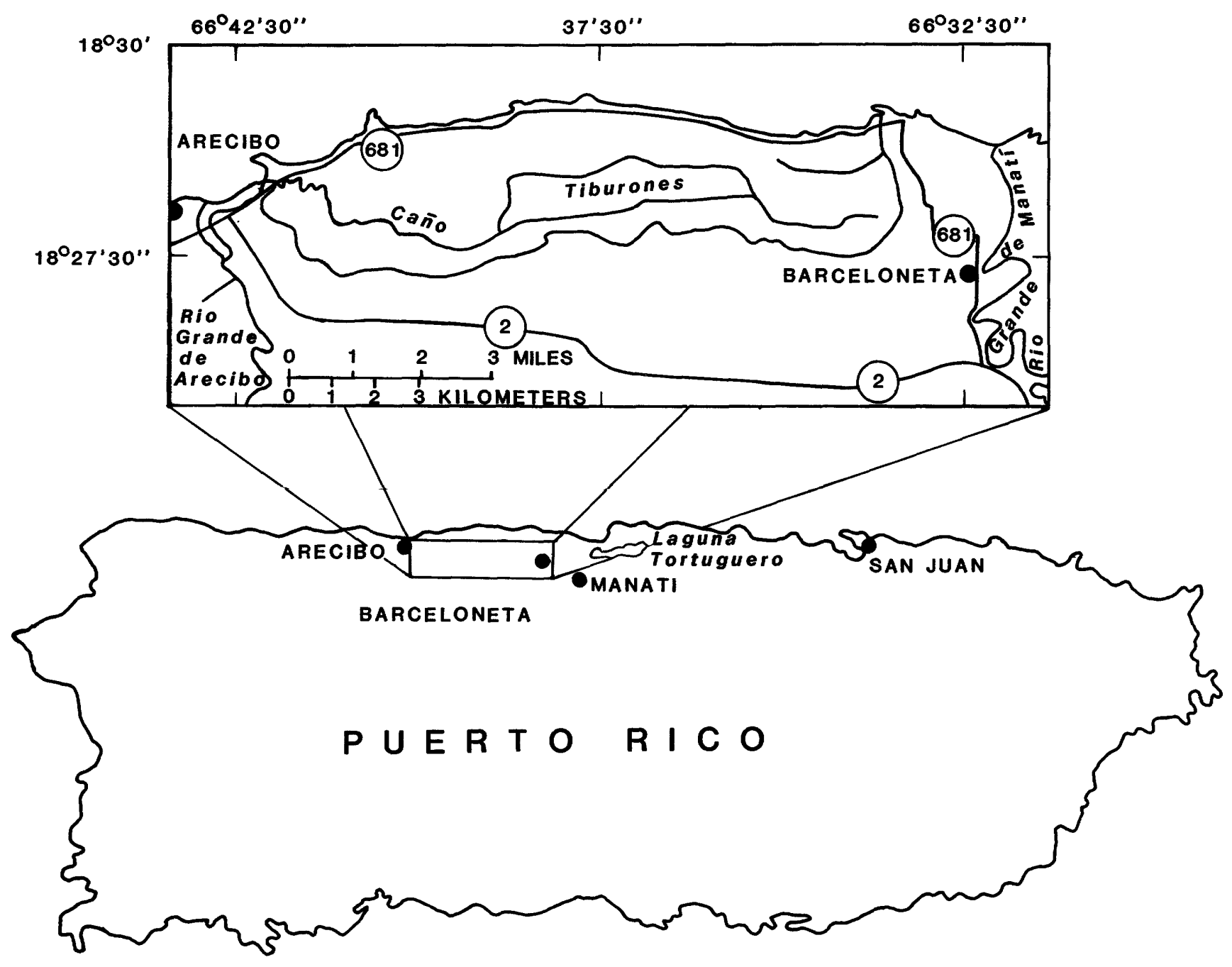

Figure 1.--Caño Tiburones and vicinity. 


\section{ACKNOWLEDGMENTS}

The authors gratefully acknowledge the many individuals who provided assistance and cooperation throughout the project. Foremost support was provided by F.A. Johnson, hydrologist with the U.S. Geological Survey in Columbia, S.C. Throughout the data-collection phase of the investigation he worked tirelessly and offered many valuable suggestions. Without his help and encouragement, this report would have been impossible.

G. W. Leve and Kenneth Stevens, U.S. Geological Survey hydrologists in Jacksonville, Florida, and Albuquerque, New Mexico, respectively, drilled piezometers and wells and made initial interpretation of the hydrologic data obtained.

The authors are indebted to personnel with the Commonwealth of
Puerto Rico Land Authority and Rice Program who generously assisted the project in the earth-moving and extensive rerouting and damming program. Special mention must be made of Agustín Cayere, Luis Picó, Marcos Mercado, and Eliseo Sánchez and his staff.

\section{DESCRIPTION OF THE AREA}

The climate of the Caño Tiburones is warm, tropicalmarine, with very small fluctuations in temperature. Annual rainfall averages about 55 inches (at Arecibo), but is not evenly distributed throughout the year. Two recording rain gages placed within the Caño (fig. 2--in pocket) have shown that rainfall is at least 10 percent less than that at Arecibo, owing to a strong orographic effect. The rainiest month is May; second rainiest are 


\section{DESCRIPTION OF THE AREA (Continued)}

October and November. A relatively

dry season extends from January

through April. Even with these

variations in rainfall, the

climate of the area is ideal for

agricultural activity throughout

the year.

Río Grande de Arecibo bounds

the Caño Tiburones on the west and has great potential as a source of irrigation water for the area. The average discharge of the Río Grande de Arecibo at Central Cambalache (11 years of record, 1970-1980) is $496 \mathrm{ft}^{3} / \mathrm{s}$ (USGS, 1982, p. 49). During this period flows have ranged from $50 \mathrm{ft}^{3} / \mathrm{s}$ to 23,700 $\mathrm{ft}^{3} / \mathrm{s}$. Flow at Arecibo is regulated by hydroelectric power production at Dos Bocas reservoir, 12 miles upstream of the Cambalache gage.

\author{
eastern border, has less potential \\ as a source of irrigation water \\ for the Caño area. Although its \\ average discharge (10 years of \\ record, 1971-1980, USGS, 1982, \\ p. 70) is $368 \mathrm{ft}^{3} / \mathrm{s}$, seawater is \\ known to intrude upstream in Río \\ Grande de Manati as far south as \\ the town of Barceloneta. Seawater \\ intrusion into Río Grande de \\ Arecibo never extends past its \\ mouth.
}

Studies of the soils in the Caño Tiburones have shown that the area is suitable for a wide variety of agricultural uses, including the growing of rice (Bonnet and Roberts, 1967, pp. 29-67). First, however, the accumulated salts - composed principally of sodium chloride must be flushed from the soils and freshwater established in the canal and lateral system.

Río Grande de Manatí, on the 


\section{HISTORY OF THE CAN̄O TIBURONES}

Caño Tiburones was originally

a brackish, shallow, coastal

lagoon (Meyerhoff, 1933, p.87)

similar to what Laguna Tortuguero

(fig. 1) is today. According to

tradition, local fishermen

adopted the name Caño Tiburones

as an attempt to dissuade outsiders

from fishing the exceptionally

rich but "shark infested" waters.

Before reclamation, water in

the Caño was composed of freshwater

and saltwater components: fresh-

water from rainfall, overbank flow

of the adjoining Río Grande de

Arecibo and Río Grande de Manatí

during floods, overland runoff from

the southern uplands, and spring-

flow; saltwater entered the area

from high tides and from migrations

up river channels during periods of

low flow. Freshwater predominated

when tides were low and rainy con-

ditions existed; saltwater was

evident during droughts, when tides were high. The area drained seaward through the river basins on either side and through large subterranean conduits, unknown at the time, which connected the area directly with the ocean.

The scarcity of land resources in Puerto Rico for agriculture prompted engineers in 1907 to drain the Caño Tiburones by gravity, using closely-spaced herringbone laterals. Overland floodwater vents to the ocean were constructed at E1 Vigía and at Palmas Altas (fig. 2--in pocket).

Drainage was accompanied by a gradual dewatering of the soils, resulting in soil shrinkage and land subsidence. Linear desication cracks, often extending below the water table and 1ocally known as "cancoras," developed from shrinkage of the highly organic soils. 


\section{HISTORY OF THE CAÑO TIBURONES (Continued)}

Land subsidence continued as water

was drained until the elevation

of the water table eventually

approached sea level. Further

gravity drainage of the soil zone

became impossible, and in 1949,

four low-1ift turbine pumps, each

rated at $80,000 \mathrm{gal} / \mathrm{min}$ were

installed at E1 Vigía. An

improved tidal gate was constructed

at Palmas Altas $1 /$ and a more

efficient arrangement of laterals

and canals was provided for

draining accumulated water

(fig. 2--in pocket).

Continuous removal of water

from Caño Tiburones by the pumping

station at E1 Vigía further de-

pressed the water table until it

was 1 owered below sea leve1, there-

by reversing the hydraulic gradient

with the ocean. The heretofore un-

observed conduits which originally

vented accumulated water now per- mitted seawater to enter the Caño area. With additional subsidence of the land surface, more pumping was required to lower the water table which increased the hydraulic gradient from the ocean to the Caño. Subsequently, more seawater entered the area requiring additional pumping to maintain static levels throughout Caño Tiburones. Norma1, dry conditions required approximately 37 pump-hours per day to maintain equilibrium waterlevels and salinity throughout Caño Tiburones.

The continuous presence of saltwater in many parts of the Caño has, through the years, permitted the accumulation of sodium chloride in the soil. Saltwater infiltrated the soil zone from the canals and laterals by percolation and capillary action. The water was then removed

1/ Original plans called for the construction of another pumping plant at Palmas Altas, but funds were exhausted after the plant at E1 Vigía was completed (oral commun., Salvador García, May 1979). 


\section{HISTORY OF THE CAÑO TIBURONES (Continued)}

by evapotranspiration, and residual salts, mainly sodium chloride were left behind in the soil. The organic soils which occur throughout the Caño, once drained and dry, resist rewetting and are almost impermeable. Therefore, rainfall has been ineffective in flushing away the accumulated sodium chloride in the soil. Occasional flooding from pump shutdowns has contributed to widespread sodium-chloride contamination. The most recent pump shutdown at El Vigía occurred in July 1977 and lasted 20 days during which time Caño Tiburones became flooded with seawater. Water from the ocean entered the area through the subterreanean conduits and reached an elevation of mean sea level within two days. When pumping began and water levels declined, residual sodium chloride from evaporation of the ponded saltwater remained over a wide area in the upper few inches of the organic soil.

\section{SURFACE HYDROLOGY OF CAÑO TIBURONES BEFORE WATER MANAGEMENT}

The present investigation into the freshening potential of the Caño Tiburones began in Spring 1979. At that time there was no pattern or consistency of flow within the system. Water in laterals was permitted to flow either north or south and canals, east or west. In addition there was no pattern to the distribution of saltwater in the canals and laterals (fig. 3--in pocket).

Generally, Canal Norte collected the saltiest water from nearby subterranean conduits or "springs" which discharged to adjoining canals and laterals, all below sea level. The conduits discharged crysta1-clear water and contained myriad seawater fishes and molluscs. Some conduits formed discharging pools, hundreds of feet in diameter, and over 50 feet deep at the spring orifice. Figure 4 shows the 


\section{SURFACE HYDROLOGY OF CAN̄O TIBURONES \\ BEFORE WATER MANAGEMENT (Continued)}

complexity of one of the smaller

"spring pools." Some conduits

flowed as much as $20 \mathrm{ft}^{3} / \mathrm{s}$; others

were on1y seeps. Al1, however,

flowed continuous1y and would have

a head of approximately sea level

if flow was blocked. It was not

known if the conduits were the only

source of salinity in the Caño;

nor was it known if each conduit

was hydraulically independent of

the others.

Freshwater springs and seeps

a1so were found to contribute water

to the Caño flow system (fig. 2--in

pocket). These were concentrated

generally in the area of Canal

Central, although some were

observed to occur nearer to the

coast and within 10 feet of

seawater conduits. The largest

of the freshwater springs were

located in the southwest part of

the Caño and flowed as much as
$20 \mathrm{ft}^{3} / \mathrm{s}$, but in most areas the

freshwater inputs were seeps.

Hydraulic head tended to decrease

toward the coast but always was

lower than sea level. The specific

conductance of freshwater springs

ranged from 1,100 to 1,300 microm-

hos per centimeter (umhos/cm).

The percentage of freshwater

observed in the canals and 1aterals

increased dramatically with heavy

rainfalls. Runoff immediately

entered adjoining laterals and

canals. Some floodwater vented to

the ocean through tidal gates at

Palmas Altas and through siphons;

the remainder was discharged to the

ocean through the pumping station

at El Vigía. Heavy rainfalls re-

quired that all four pumps $2 /$ be

in operation. Pumping of the ex-

cess water would usually return

water levels in the canals to

prerainfall levels within 24 hours.

2/ At the beginning of the study, it was determined that the pumps had lost some efficiency; their individual estimated capacities ranged from 50,000 to $56,000 \mathrm{gal} / \mathrm{min}$. 


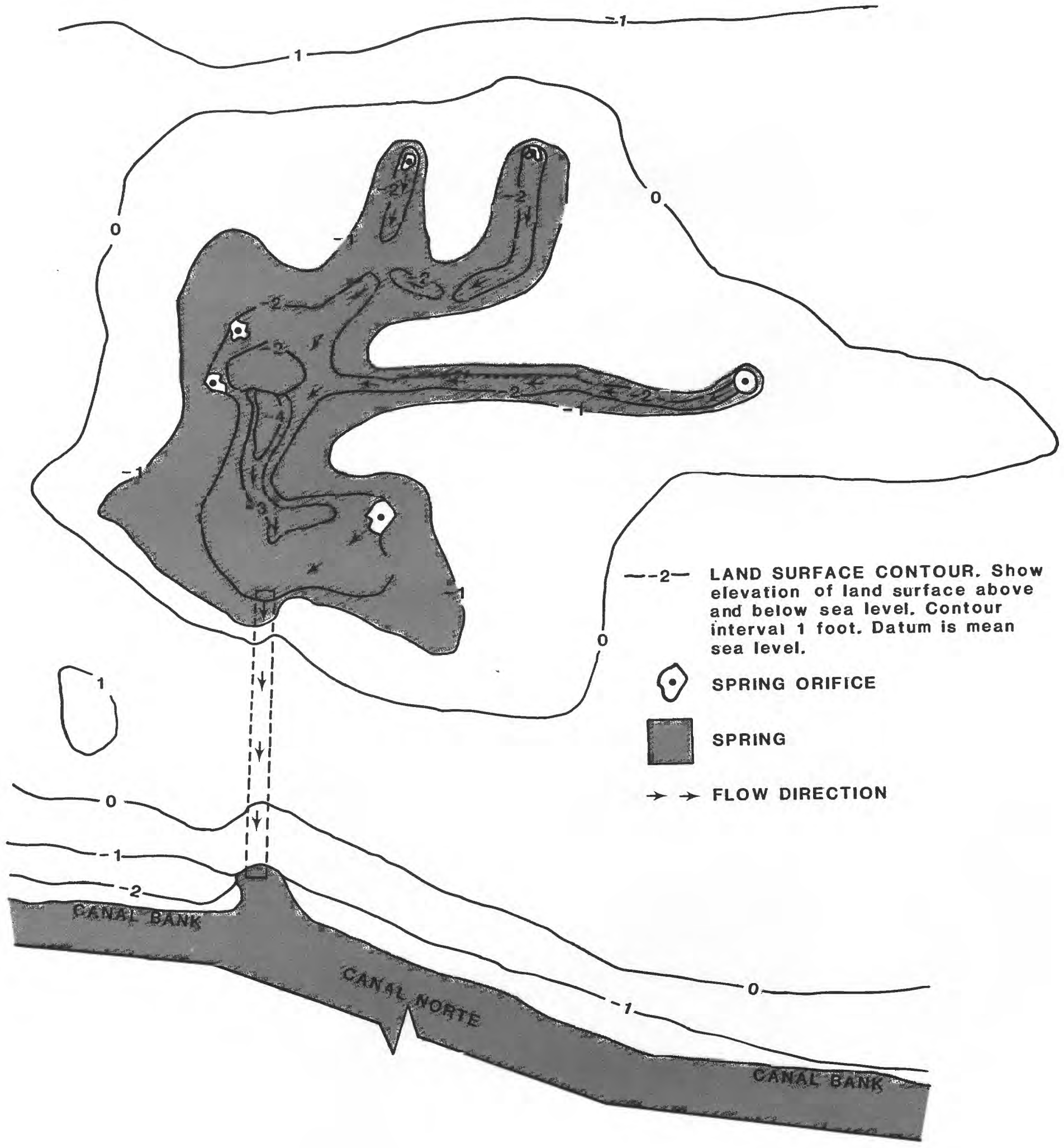

Figure 4.--Land surface altitude in vicinity of Poza Dorada a seawater spring, or seep, draining to the Canal Norte of Caño Tiburones. 


\section{SURFACE HYDROLOGY OF CAÑO TIBURONES BEFORE WATER MANAGEMENT (Continued)}

The salinity of the water in the canals and laterals returned to equilibrium levels in a matter of days because of immediate seawater replacement of freshwater and zero bank storage of rainfall.

Since 1970 , the saltwater situation in the Caño Tiburones has been exacerbated by seawater leakages through the tidal gates at Palmas Altas. Local fishermen forced tires and other objects into the tidal flaps to allow seawater into the Caño to improve crabbing and fishing. The siphons discharging to the Río Grande de Manatí had been altered for no apparent reason, allowing water to move either way through them, and had on occasion leaked seawater to the Caño. As a result, high tides at the mouth of Río Grande de Manatí and sewage discharges containing saline water from a sewagetreatment plant at Barceloneta also contributed large quantities of salty water into the area through the siphons. 


\section{GEOHYDROLOGY}

The Caño Tiburones consists of swamp deposits and limey blanket sands as much as 100 feet thick (Díaz, 1973, plate 2) of Holocene and Pleistocene age. The swamp deposits were probably deposited when cross flows existed between Río Grande de Manatí and Río Grande de Arecibo. Rich, organic soils containing large quantities of plant remains are evidence of past, rich, floral assemblages. The blanket sands are partly derived from dissolved limestone residues (Briggs, 1966, p. 60). The swamp deposits and blanket sands are bounded by alluvial deposits of sand and gravel deposited by Río Grande de Arecibo and Río Grande de Manatí. Underlying the entire area is the Aymamón Limestone, of early Miocene age. Giusti and Bennett (1976, p.33) showed that Río Grande de Arecibo loses flood flow to underlying alluvium and the Aymamón Limestone. They concluded that some of this water subsequently discharges to the Caño Tiburones as freshwater springflow described earlier, presumably through the Aymamón Formation.

The Caño is separated from the ocean by calcite-cemented sand dunes (eolionite), beach sand, and remnants of the Camuy Formation, also a limestone of Miocene age, but younger than the Aymamón. The subterranean conduits described earlier apparently developed by dissolving limey parts of the Camuy Formation and the eolionite when the water-table elevation in the Caño was greater than sea level.

$$
\text { Limestone hills (mogotes) }
$$
composed of the Aymamón Formation bound the area on the south. These mogotes are residual limestone hills formed by solution of limestone beneath the blanket sands (Monroe, 1976, p. 46). 


\section{GEOHYDROLOGY (Continued)}

An in-depth discussion of ground-water flow is beyond the scope of this investigation because ground water is neither the source nor the cause of salinity in the Caño flow system and in the soil. However, because fresh springflow constitutes the principal source of water to Caño Tiburones, its relation to artesian pressures in the Aymamón Limestone will be discussed briefly.

Where deep fissures or highly permeable zones occurred in the blanket sands and swamp deposits and penetrated to or were in contact with the Aymamón Limestone, water was freely transmitted upward to be discharged as freshwater springs. However, where tight, virtually impermeable soil occurred above the Aymamon, ground water under artesian pressure in the Aymamón migrated upward through the sediments progressively losing hydraulic head to be discharged at the surface as seeps.

The constant removal of water from the Caño by pumping and the long-term maintenance of the same water-level elevation throughout the area had, up until 1970 or so, established equilibrium heads in the Aymamón. Since that time, however, artesian pressures have declined in the Aymamón Limestone, probably attributable to groundwater withdrawals south of the area along Highway 2. The effect that artesian pressure decline has had on the amount of freshwater that ultimately enters the flow system of Caño Tiburones has not been clearly defined.

It would appear that the percentage of freshwater in the brackish mixture discharged at E1 Vigía during dry (equilibrium) conditions would decrease in 


\section{GEOHYDROLOGY (Continued)}

accordance with artesian-pressure

decline in the Aymamón. This

has not been the case. The percent-

age of freshwater in the brackish

mixture measured during dry condi-

tions by various investigators

over the past 20 years has

remained the same: 66 percent

or approximately $78 \mathrm{Mgal} / \mathrm{d}$. This

phenomenon is probably attributable

to the importance of the Río Grande

de Arecibo in recharging nearby

parts of the Aymamón Limestone.

The water discharges from the

Aymamón as springflow and seepage

and would not be measurably

affected by a decline in artesian

pressure from ground-water with-

drawals away from the area along

Highway 2. It is possible that

freshwater seepage has kept relatively constant in spite of

ground-water level declines in the

eastern Caño area because of

accompanying land subsidence. The

effective ground-water gradient

has remained the same.

It is also possible that

the decline in artesian pressure

in the Caño area has not been

great enough to significantly

affect the flow of the springs.

Three wells drilled into the upper

part of the Aymamón Limestone in

1981 indicated that heads were

above the land surface in the Caño,

but were approximately two feet

below mean sea level (table 1).

It is assumed that this elevation

represents the freshwater spring

head in Caño Tiburones. 


\section{GEOHYDROLOGY (Continued)}

\section{Table 1.--Representative values of specific conductance and water levels at various depths in wells plus specific conductance in adjacent canal in the Caño Tiburones area.}

\begin{tabular}{|c|c|c|c|}
\hline $\begin{array}{l}\text { WELL } \\
\text { NUMBER }\end{array}$ & DATE & $\begin{array}{l}\text { DEPTH BELOW LAND } \\
\text { SURFACE, FEET }\end{array}$ & $\begin{array}{l}\text { SPECIFIC } \\
\text { CONDUCTANCE } \\
\text { MICROMHOS / } \\
\text { CENTIMETER }\end{array}$ \\
\hline $\begin{array}{c}\text { Central } \\
\text { Canal } \\
1\end{array}$ & $\begin{array}{l}\text { 1-15-80 } \\
\text { Do. } \\
\text { do } \\
\text { do } \\
\text { do } \\
\text { do } \\
\text { do } \\
\text { do } \\
\text { do }\end{array}$ & 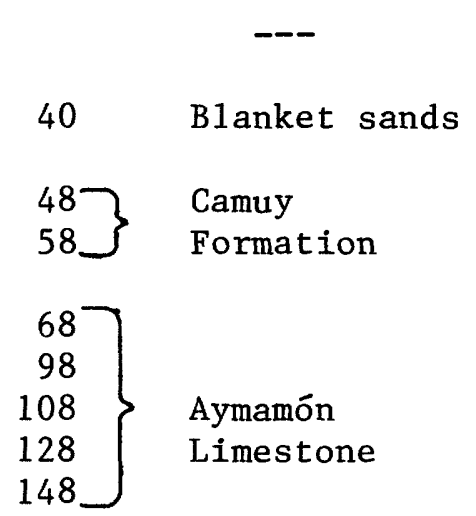 & $\begin{array}{l}13,000 \\
1,500 \\
1,950 \\
2,000 \\
1,800 \\
2,200 \\
2,200 \\
2,500 \\
4,800\end{array}$ \\
\hline $\begin{array}{c}\text { Latera1 } \\
2\end{array}$ & $\begin{array}{l}1-12-80 \\
\text { do } \\
\text { do } \\
\text { do } \\
\text { do } \\
\text { do }\end{array}$ & $\left.\left.\begin{array}{rl}58 \\
60 \\
78\end{array}\right\} \quad \begin{array}{l}\text { Camuy } \\
\text { Formation } \\
88 \\
108\end{array}\right\} \begin{array}{l}\text { Aymamón } \\
\text { Limestone }\end{array}$ & $\begin{array}{l}4,500 \\
1,100 \\
1,400 \\
1,400 \\
1,750 \\
2,600\end{array}$ \\
\hline $\begin{array}{c}\text { North } \\
\text { Cana1 } \\
3\end{array}$ & $\begin{array}{c}\text { 1-10-80 } \\
\text { do } \\
\text { do } \\
\text { do } \\
\text { do } \\
\text { do } \\
\text { do } \\
\text { Do. }\end{array}$ & $\begin{array}{l}\text { Blanket sands } \\
\text { Camuy } \\
\text { Formation } \\
\text { Aymamón } \\
\text { Limestone }\end{array}$ & $\begin{array}{r}32,000 \\
2,500 \\
3,400 \\
3,500 \\
\\
2,850 \\
2,850 \\
4,600 \\
6,000\end{array}$ \\
\hline
\end{tabular}




\section{GEOHYDROLOGY (Continued)}

The decline in artesian

pressure has affected the upward

migration of water through the

blanket sands and swamp deposits.

The near-surface vertical hydraulic

gradient apparently has changed

during the past 10 to 15 years

since the advent of large ground-

water withdrawals south of the

area. Studies of the near-

surface hydrology between October

1966 and April 1968 indicated

that widespread upward seepage

occurred through the upper 28 feet

of sediment ( $Q$ uiñones and Others,

1970 , p. 21). At the time, Quiñones

reported that most of the piezo-

meters finished at a depth of 28

feet produced flowing wells.

Thirty shallow piezometers

ranging in depth from six inches

to $33 \mathrm{ft}$ and drilled in 1980

indicated that the hydraulic

gradient in the near-surface

saturated sediments has reversed

(table 2). Apparently, the loss of pressure in the Aymamón has reduced the height to which water can be pushed in the tight, impermeable soil above the Aymamón. Accordingly, soils are now draining in response to the pressure decline in the Aymamón. The extremely low percolation rate prevents the saturated sediment from draining very quickly in response to the loss of pressure. Further reductions of pressure in the Aymamón Limestone will probably be accompanied by a further lowering of the water table (soil drainage) throughout Caño Tiburones, but will probably not measurably affect freshwater springflow in the southwestern part of the Caño because much of it probably originates as seepage loss from Río Grande de Arecibo.

During the present investigation, chloride-ion measurements in the piezometers and wells 


\section{GEOHYDROLOGY (Continued)}

indicated that salinity decreased with depth generally being the least in the upper part of the Aymamón (tables 1 and 2). This is further evidence that much of the Caño Tiburones is present1y draining. Had the area been discharging ground water upward through the sediments, the water quality would probably have been the same as that in the underlying Aymamón Limestone. Higher than water-table heads in canals and laterals containing seawater allow slow downward and lateral percolation of surface water, with subsequent mixing through diffusion and dispersion; hence salinity decreases with depth. The distribution of saltwater in the soils and the surficial material in the Caño complements the distribution of salty water in the canals (table 2), (fig. 3--in pocket). The conductivity profiles in canals approximate those of the soil regime adjacent to the canal.
The water throughout the Caño represents a mixture of freshwater and seawater. The ratio of sodium to chloride in water from the Caño is the same as the sodium to chloride ratio of seawater (fig. 5). The relation between chloride and the ratio of calcium to magnesium shows nonconservative mixing between seawater and calcium carbonate ground water (fig, 6). Seawater necessarily has a low calcium to magnesium ratio because sea animals selectively remove calcium ions from seawater and form calcium carbonate for shells (molluscs) and skeletal structure (corals). What remains is seawater with a $\mathrm{Ca} / \mathrm{Mg}$ ratio (in $\mathrm{mg} / \mathrm{L}$ ) of about 0.3. Terrestrial waters, regardless of their sodium and chloride concentrations, will usually have a much higher ratio because of the greater proportion of calcium to magnesium in the rocks of the earth. In addition, 
GEOHYDROLOGY (Continued)

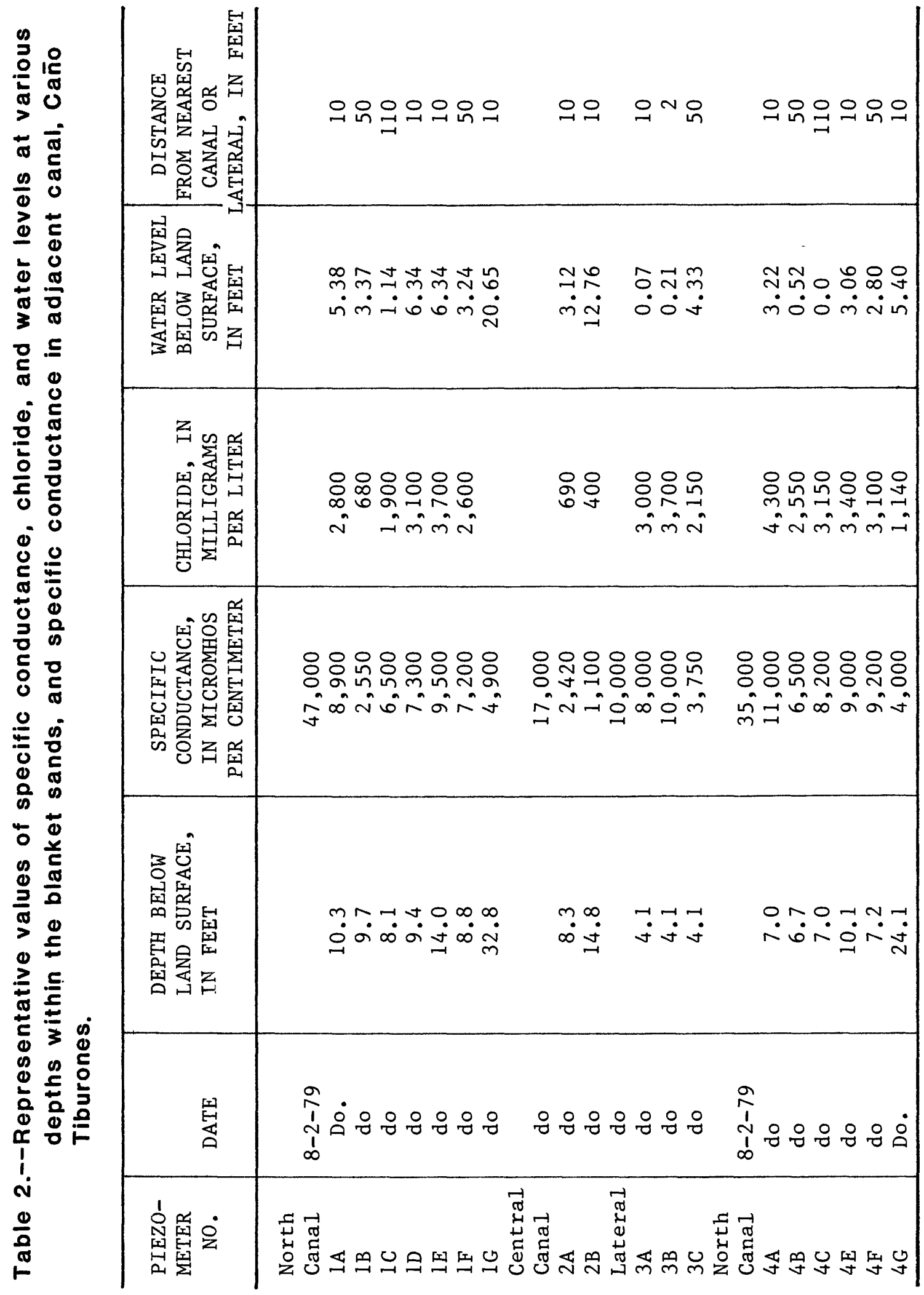




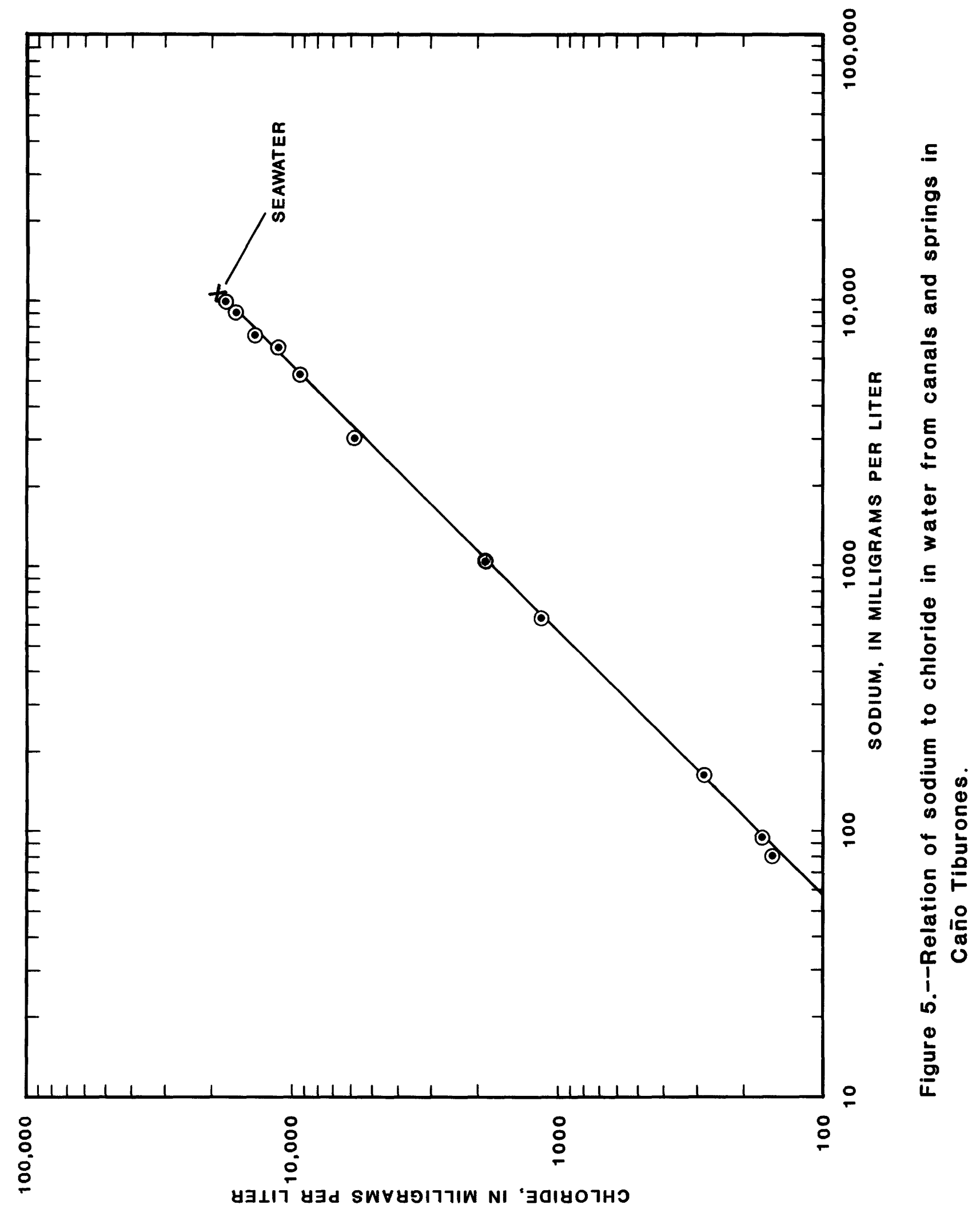




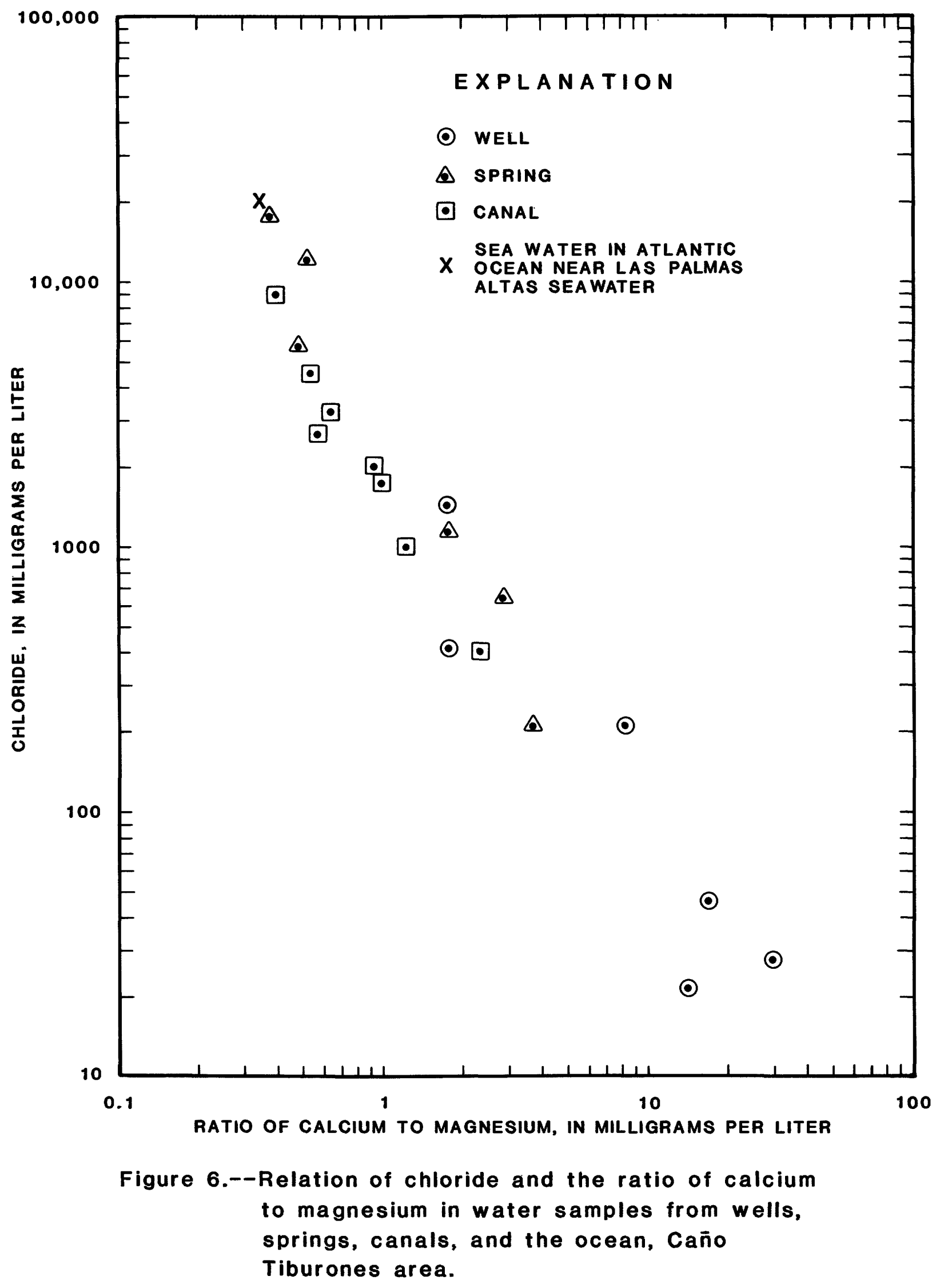




\section{GEOHYDROLOGY (Continued)}

seawater slowly percolating through the calcium-rich limestone in the vicinity of Caño Tiburones would, over a very long period of time, reach a solubility-product equilibrium which permits a greater concentration of calcium (and lesser concentration of magnesium) in accordance with the law of mass action and the relative quantities of calcium and magnesium in the limestone.

Accordingly, the geologic and geochemical evidence of the seawater derivation of sodium chloride in the Caño Tiburones precludes the hypothesis that salinity is derived from underlying calcareous rocks. The evidence sustains the theory that all sodium chloride encountered in the Caño is derived from direct hydraulic connection with the ocean for if it were not, the water in the Caño would have a greater concentration of calcium to magnesium and a ratio of sodium to chloride greater than that of seawater.

\section{SEGREGATION OF SALTWATER AND FRESHWATER}

Flow measurements and conductivity profiles originally made in the canals and laterals of Caño Tiburones indicated that the concentration of saltwater in the system was related to its nearness to saltwater conduits. However, owing to the flat hydraulic gradient throughout the Caño, flow could proceed in any direction depending only on minute differences in head between points within the canal and lateral system. The general movement of water in the canals was east to west, toward the pumping station at El Vigía. However, on occasions, water was observed to move toward the east in the eastern part of the Canal Central. 


\section{SEGREGATION OF SALTWATER AND FRESHWATER (Continued)}

The absence of a pattern or consistency of flow permitted free mixing of saltwater and freshwater throughout the Caño (fig. 3--in pocket). In order to force the system to flow in one direction only and at the same time segregate freshwater from saltwater, a program was initiated by the Puerto Rico Department of Agriculture in February 1980 to rehabilitate many of the flow structures in the Caño Tiburones and construct dams at appropriate locations in the canals and laterals.

Two large earthen dams were built across canals: one in Canal Central, just before its western union with the Canal Norte; and one in the Canal Norte at its eastern extent (fig. 7--in pocket). The dams established a new hydraulic gradient from south to north across the canals and laterals. Freshwater from springflow accumulated in Canal Central at the same time water levels in Canal Norte were depressed by pumping at E1 Vigía.

Dams were also built across laterals to direct the drainage from seawater conduits and springs. Laterals draining seawater conduits were forced to drain northward to Canal Norte by dams which isolated them from Canal Central. In laterals draining freshwater springs, dams were placed at their northern extent to isolate them from Canal Norte. Concurrently, important laterals were cleaned and dredged by dragline, and appropriate culverts were repaired or replaced so a south-to-north or a north-to-south drainage could proceed. The flow system was engineered to distribute fresh springflow to each north-flowing lateral, so that all parts of the Caño flow system would be equally flushed of accumulated salts. 
SEGREGATION OF SALTWATER AND FRESHWATER (Continued)

The importance of maintaining an effective hydraulic gradient from south to north and the position of freshwater and seawater inputs to the system required considerable restriction of flow in the western laterals (by constriction) and unimpeded flow of eastern laterals.

After a week or so, equilibrium conditions prevailed in the Caño under the new flow regime (fig. 7--in pocket). Canal Centra1 and laterals draining freshwater springs accumulated and distributed freshwater to laterals hydraulically connected to Canal Norte. Laterals which did not drain springs, were permitted to flow south-to-north, unimpeded by dams. Laterals draining seawater conduits, prevented from flowing south, drained to Canal Norte. Canal Norte served as a sacrificial canal for collected seawater and for drainage from Canal Central.
CONTAINMENT OF SEAWATER ENTERING CAÑO TIBURONES

The principal source of seawater to Caño Tiburones since reversal of the hydraulic gradient has been the constantly flowing seawater conduits, directly connected to the ocean. Until the conduits were plugged, sealed, or otherwise checked, the Caño Tiburones was unable to become any fresher than that obtainable by the dam emplacements alone (fig. 7--in pocket).

Plugging or sealing of the hundreds of seawater conduits was virtually impossible. Assuming that an effective sea1 could be determined and injected or installed in each conduit, maintenance difficulties would be a recurring problem. In addition, it was not known with certainty if: (1) the hydraulic head in every seawater conduit would approach sea level if it were 


\section{CONTAINMENT OF SEAWATER ENTERING CAN̄O TIBURONES (Continued)}

prevented from flowing and,

each conduit was hydraulically

independent of the others. Clearly,

the plugging of a major seawater

conduit would necessarily increase

flows in nearby conduits if they

were hydraulically connected,

particularly if heads were much

higher than anticipated.

Several sites were selected

to examine the head and hydraulic

independence of the conduits. At

each site the head and flow of

all nearby seawater conduits were

measured. A large, centrally

located conduit was selected and

a dike or ring levee was placed

around the conduit and increased

in height until the conduit stopped

flowing. The new equilibrium water

level of the diked conduit in-

creased approximately 2-1/2 feet,

or about the elevation of sea

level. After equilibrium condi-

tions returned to the flow system,

heads and flows of the adjacent conduits were measured again. There was no increase of head or flow observed in the adjacent seawater conduits. Had there been hydraulic connection between conduits, the system would have readjusted its subterranean routing of flow. Hydraulic head of the diked conduit would have been somewhat less than sea level and the head and flow of the nearby conduits would have increased. The hydraulic independence of conduits was observed at all locations tested.

\section{If all seawater conduits}

maintained a head consistent with that of mean sea level and were hydraulically independent, they could be stopped from flowing by constructing dikes around their periphery. Beginning in July, 1980 a program was begun by the Department of Agriculture to construct earthern dikes around all seawater conduits to a height of approximately $1-1 / 2$ feet above mean sea 


\section{CONTAINMENT OF SEAWATER ENTERING CAN̄O TIBURONES (Continued)}

leve1. Where draglines could not be supported by the soils or where myriad conduits occurred in a small area, ring levees were placed around entire fields. Approximately 20 individual dikes were built. The dammed seawater quickly reached mean sea leve1 because it was prevented from draining into adjoining laterals or canals. The vast majority of seawater was stopped from leaking into the flow system.

The result of emplacing ring levees around the seawater conduits can be realized by observing the level of salinity now measured in the canal system (fig. 8--in pocket). With seawater blocked from the system, the entire Caño Tiburones becomes progressively fresher with time. Every rainfal1 replaces more of the residual saltwater in the system. If the dams are maintained and all seawater entrances checked, even
Canal Norte can be used as a source of irrigation water when remaining saltwater in canals, laterals, and soils is eventually flushed from the area. As discussed earlier, sodium chloride adheres tenaciously to the highly organic, impermeable soil. Rainfall is ineffective in washing away the accumulated salts. However, by damming individual fields and applying freshwater, the fields can be planed and furrowed, thereby rewetting the upper foot or so of soil. Subsequently, the water can be brought into contact with more soil surface and more sodium chloride can be liberated to the water. Upon draining, reapplication of freshwater, and further mixing, soils can be flushed of the sodium chloride. It is estimated that for 75 percent of the fields in the Caño, one flushing of the soil will be 


\section{CONTAINMENT OF SEAWATER ENTERING CAN̄O TIBURONES}

\section{(Continued)}

required to reduce sodium chloride to levels acceptable for most agricultural purposes, including rice cultivation. At the more salty sites, more than one flushing may be necessary.

\section{TESTING EQUILIBRIUM WATER LEVELS BY STOPPING PUMPING AT EL VIGIA}

In the past, the stopping of pumping at $E 1$ Vigía resulted in widespread saltwater flooding in which the height of water in the Caño Tiburones reached sea level. An experiment was performed on April 5, 1982 to measure waterlevel responses to a pump stoppage with the seawater conduits (and other seawater entrances) blocked. At 9:00 A.M. on April 5, the pumps were turned off for the first time since July 1977 and water-level response was measured for 4 days (fig. 9).

The time rate-of-change of water level rise in the canal at the El Vigía pumphouse decreased logarithmically and approached the freshwater spring head some two feet below sea level. Although some minimal flooding occurred, the test demonstrated that continuous pumping at El Vigía was no longer required to keep water from flooding throughout the valley now that seawater conduits were secured. 


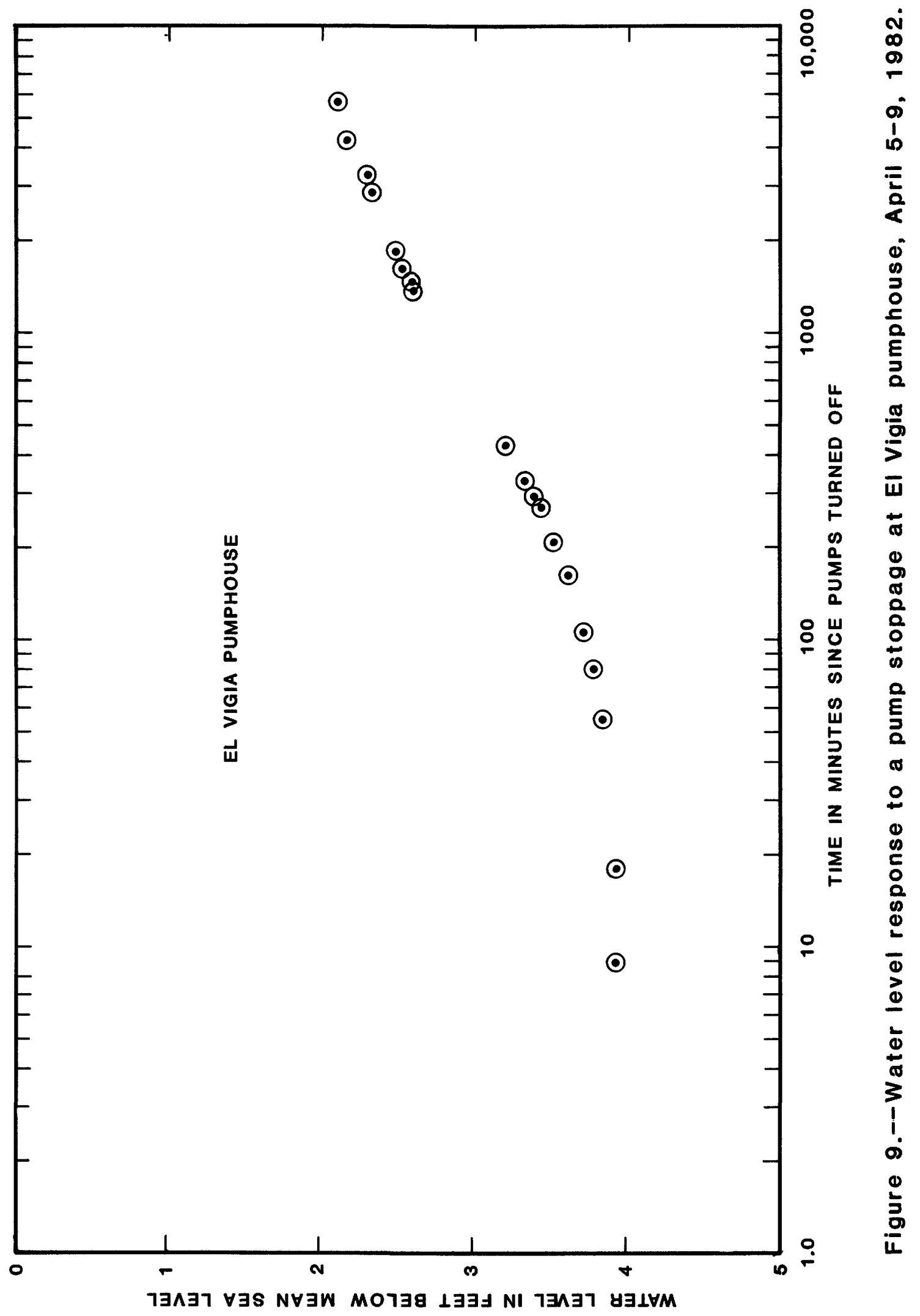




\section{MEASUREMENT OF FRESHENING EFFORTS IN CAN̄O TIBURONES}

\author{
Efforts in improving flow \\ conditions and establishing \\ freshwater within the Caño were \\ continuously monitored by digital, \\ specific-conductance recorders, \\ placed at strategic 1ocations \\ throughout the area (fig. 2--in \\ pocket). The recorders were \\ installed in July 1979 and are \\ sti11 maintained (February 1984). \\ A1though there has been some \\ missing record from malfunctions \\ and vandalism, the results are \\ highly informative.
}

Before rerouting the flow, salinity varied widely throughout the Caño and the amplitude of 1ongterm daily conductivity fluctuations (caused by lower nightime pumping rates) was about 10,000 umhos/cm in Canal Norte. Three stations at sites A, B, and C (fig. 2--in pocket) demonstrate the changes in salinity (fig. 10). Background conductivities at station A, B, and C were 18,000 ,
44,000 , and 17,000 umhos respectively. Rainfall associated with Hurricanes David and Frederick (approximately 10 inches in 7 days) freshened the Caño for several days in early September 1979. After the rain stopped, seawater flow from the conduits replaced the freshwater and the salinity returned to its previous high levels in about 6 days.

Soon after the dams were constructed, the dramatic effects of freshening solely by fresh springflow throughout the Caño were observable (fig. 10). Water consistently moved in one direction; ponding of saltwater in the canals and 1aterals was avoided and smaller fluctuations of specific conductance recorded. Water from rainfa11 also 1ingered in both Canal Central and south-flowing laterals twice as long as before the dams were built, causing the freshening effects of rainfa11 to last much 1 onger. 


\section{MEASUREMENT OF FRESHENING EFFORTS IN CAÑO TIBURONES (Continued)}

After the seawater springs were contained, the salinity in the canal system improved greatly (fig. 10), and continues to improve with the contribution of freshwater from springs and with the additional emphasis from each rainfall. In May 1982 the eastern dam in Canal Norte was moved to Canal Central because of sewage discharges from a sewage-treatment plant at Barceloneta. This further improved conditions in Canal

Central. Amplitudes have been significantly reduced and the freshening effects of rainfall are even more long-lasting.

The fraction of seawater (based on conductivity measurements) in the entire canal and lateral system of Caño Tiburones during periods of dry weather in 1979 was 34 percent. As of August 1982, the amount of seawater has declined to 15 percent and this percentage is now decreasing daily. The Canal Central contains one eighth the seawater it contained in 1979. Today water from Canal Central and north-flowing laterals can be used for irrigation. With time and maintenance of the dams and canals, Canal Norte also will become much fresher. Some water with a higher specific conductance lingers in low, stagnant reaches of the canal system. Laterals which transmit water from south to north are not as deep as the canals; therefore, complete flushing of Canal Central by freshwater springflow and rainwater is impeded.

A small quantity of seawater drains into Canal Central just before El Vigía and is responsible for the elevated levels of specific conductance observable in figure 10 for the pumphouse monitor. It appears to be important only when high water levels are maintained in the Caño. 


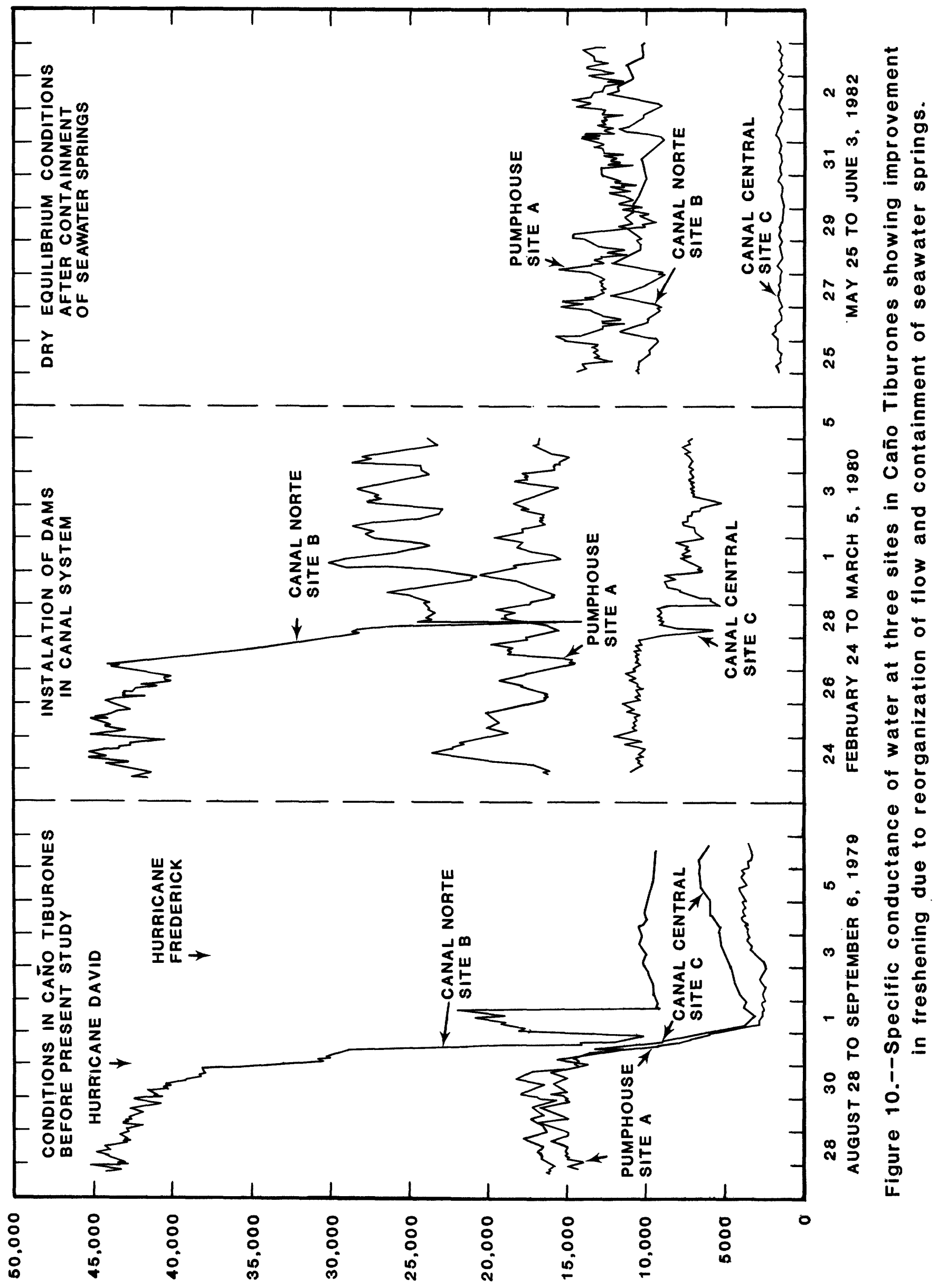




\section{CONCLUSIONS}

There are three major findings of the Caño Tiburones freshwaterrestoration project:

1) Ground-water discharge is not the cause of salty conditions in Caño Tiburones. A test-drilling program verified that ground water in the vicinity of the Caño was much fresher than surface water. In addition, the low hydraulic conductivity of blanket sands and swamp deposits prevents significant upward or downward percolation.

\section{2) Seawater entering the} Caño through subterranean conduits is the source of salinity in the canals and laterals. This was determined by conductivity profiles and by chemical analysis. Relations of sodium to chloride and calcium-magnesium ratios of Caño water verify its derivation from seawater.
3) Salinity of organic soils is attributed to (a) infiltration and capillary action by saltwater from adjacent canals and laterals and, (b) flooding of the land surface by saltwater where pumping at El Vigía was stopped. In each case subsequent evapotranspiration concentrates the salinity.

The soils of Caño Tiburones are no longer accumulating sodium chloride. The surface-water system, now much fresher, aids the flushing of residual salinity in the Caño flow system. Flushing of soil will necessarily proceed slowly and will leach large quantities of sodium chloride to the canal and lateral system for some time. As soils become fresher, the salinity of the water in the Canal Norte will lessen. 


\section{CONCLUSIONS (Continued)}

Soil flushing and irrigation of the Caño Tiburones can be expedited by using water from other sources such as Río Grande de Arecibo. Canal Sur as well as the Canal Central are ideal reservoirs and distribution system for this water.

\section{Excess irrigation water can} be lifted to nearby dammed seawater conduits instead of being discharged to Canal Norte. The conduits, in their ability to maintain a head of mean sea level, can accept relatively large quantities of water ultimately to be discharged to the ocean. This procedure would keep canal discharges low, permitting less pumping at E1 Vigía. Conceivably, the pumps at E1 Vigia would only be used to evacuate floodwater from inordinate rainfalls and the periodic excesses of intense rice irrigation.

Dams placed at appropriate locations on canals and laterals have been used to segregate freshwater from seawater in Caño Tiburones by creating differences in hydraulic head. Ring levees prevent seawater from entering the flow system. These efforts have succeeded in reducing seawater in Canal Central and north-flowing laterals to one-eighth of their original concentration or approximately 1,800 micromhos per centimeter. At this level of specific conductance, the water can be used for most agricultural purposes. With proper maintenance of dams and levees, restoration of freshwater can be maintained. 


\section{SELECTED REFERENCES}

Bennett, G.D., and Giusti, E.V., 1972, Ground water in the Tortuguero Area Puerto Rico, as related to proposed harbor construction: Commonwealth of Puerto Rico Water-Resources Bulletin 10, 25 p.

Bonnet, J.A., and Roberts, R.C., 1967, Soil survey and salinity study of the farms in the Caño Tiburones area: Land Authority of Puerto Rico, $137 \mathrm{p}$.

Briggs, R.P., 1966, The blanket sands of northern Puerto Rico: Third Caribbean Geological Conference, Kingston, Jamaica, Geological Survey Publication 95, Tr., 60-69 p.

Díaz, José Raul, 1973, Chemical quality of water in Caño Tiburones, Puerto Rico: U.S. Geological Survey open-file report, map series 2, 2 sheets.

Gibbs and Hill, Ing., 1975, Pumping test and ground-water study Norco-NP-1, Islote, Puerto Rico, 219-317 p.

Giusti, E.V., 1978, Hydrogeology of the Karst of Puerto Rico: U.S. Geological Survey Professional Paper 899, 69 p.

Giusti, E.V., and Bennett, G.D., 1976, Water Resources of the north coast limestone area, Puerto Rico: U.S. Geological Survey Water-resources Investigations 42-75, $42 \mathrm{p}$.

Meyerhoff, H.A., 1933, Geology of Puerto Rico: San Juan, University of Puerto Rico, $306 \mathrm{p}$.

Monroe, W.H., 1976, The Karst landforms of Puerto Rico: U.S. Geological Survey Professional Paper 899, 69 p.

Perez-Escolar, R., 1977, Possible subterranean entrance of ocean water into the Caño Tiburones area in northern Puerto Rico: The Journal of Agriculture of the University of Puerto Rico, v. 61 , no.4, 484-488 p.

Quiñones, Diez, Silva y Asociados, 1970, Informe sobre estudios realizados sobre el Caño Tiburones: Autoridad de Tierras de Puerto Rico, 83 p.

Swenson, H., 1975, Why is the ocean salty?: U.S. Geological Survey, GPO 1975-587-037/51, $15 \mathrm{p}$.

U.S. Geological Survey, 1982, Water resources data for Puerto Rico, Water Year 1979-80: U.S. Geological Survey Water-Data Report, PR-80-1, 610 p. 